\title{
Birgit Schaffar \\ Om behovet att skilja mellan empiriska och begreppligt konstitutiva frågor
}

\begin{abstract}
:
This article clarifies the fundamental difference between empirical and conceptual questions in education. In the ongoing debate about the role of philosophy of education, many authors either unreflectively assume or actively demand that philosophy of education should try to adapt to (empircal) science. Through a discussion of the possibilities of a child to open up to educational processes (Herbart: Bildbarkeit) the article illustrates how philosophical reflection on education fundamentally differs in character from empirical approaches. It suggests that one important task for philosophy of education is to clarify what questions can be answered empirically from those that are constitutive of our understanding of education. Wittgenstein's later philosophy is used as a central starting point in this article.
\end{abstract}

\section{Keywords}

filosofins roll, empirisk forskning, konstitutiv-begreppsliga frågor, bildbarhet, allmän pedagogik, vetenskapskritik, Wittgenstein

Philosophy's task, empirical research, constitutive statement, conceptual question, Bildbarkeit, German tradition of general education, critique of science, Wittgenstein

\section{Tema: Hvorfor pædagogisk filosofi?}

I de tyskspråkiga och de nordiska länderna har intresset för pedagogisk filosofi ökat under de senaste 20 åren. Detta intresse tar sig å ena sidan uttryck i ett större engagemang av pedagoger inom det akademiska samfundet i innehållsliga filosofiska frågor. $\AA^{\AA}$ andra sidan förs allt oftare diskussioner kring den institutionella ställning och förankring som (pedagogisk) filosofi har inom universiteten och de enskilda fakulteterna. I regel hänvisar man till den allt mera pressade ekonomin inom universiteten då frågan ställs om t.ex. professurer med anknytning till filosofi överlag ska återbesättas. Filosofisk forskning behöver försvara sig inom en diskurs som - för tillfället - belönar effektivitet och produktivitet i form av användbara forskningsresultat och antal studieprestationer. Många filosofikritiska röster

1 I Norden grundades t.ex. the Nordic Society for Philosophy of Education år 1997, och nätverket i pedagogisk filosofi har väckt stort intresse vid den årliga konferensen som arrangeras av NFPF (Nordisk Förening för Pedagogisk Forskning), mätt i antal presentationer och deltagare (Bengtson 2001, s. 130).

Birgit Schaffar-Kronqvist, e-mail: bschaffa@abo.fi

Åbo Akademi University, Vasa, Finland

Studier i Predagogisk Filosofi | www.ojs.statsbiblioteket.dk/index.php/spf | ISSN nr. 22449140 
kräver på det viset en mera pragmatisk inställning till pedagogisk filosofi, dess uppgift och metoder. ${ }^{2}$ Den filosofiska forskningens ställning är ytterligare under tryck med tanke på den innehållsliga kritik som under förra seklet ifrågasatt den moderna filosofins försök att beskriva universella grunder till (pedagogiska) fenomen. Om filosofin har avslöjats i sin oförmåga att vara en disciplin som lägger grunden för vidare forskning, frågar sig många om det då överlag finns något som en pedagogisk filosofi, ett filosofiskt innehåll och en filosofisk uppgift kvar3 (van Goor, Heyting, Vreeke 2004)? Att en ny akademisk tidskrift i pedagogisk filosofi inleder sin verksamhet med en diskussion kring den egna legitimiteten ("Varför pedagogisk filosofi?") speglar på ett intressant sätt denna spänning mellan ökat intresse å ena sidan och ökad kritik och osäkerhet å andra sidan.

I det följande vill jag med hjälp av den diskussion som den empiriska och kritiska pedagogiken förde med en av de dåvarande ledande filosofiska grenarna inom den tyskspråkiga pedagogiken, den s.k. geisteswissenschaftliche Pädagogik, visa på en grundläggande skillnad mellan empiriska och begreppsliga, eller konstitutiva, frågor i pedagogik. Av detta drar jag slutsatsen att en pedagogisk filosofi inte borde förstås som ett slags (empirisk) vetenskap som många antingen oreflekterat utgår ifrån eller aktivt kräver av den pedagogiska filosofin. Slutligen skisserar jag en möjlig uppgift för den pedagogiska filosofin i att analysera vilka frågor i ett pedagogiskt problem som kunde vara möjliga att svara på med hjälp av ett vetenskapligt tillvägagångssätt och vilka som är konstitutiva för vår förståelse av vad den pedagogiska verksamheten själv är. De senare frågorna är av sådan karaktär att var och en som ställs inför ett pedagogiskt problem behöver ta ställning till frågorna själv. Det är på det viset varken den pedagogiska vetenskapen eller den pedagogiska filosofin som kan ge ett svar. Det som ofta kritiserades och fruktades, d.v.s. att filosofin enbart kommer att kunna utveckla en normativ ståndpunkt inom den pedagogiska diskussionen, uppstår därför inte.

\section{Empiriska och begreppsligt konstitutiva frågor - Exempel: Hur kan vi utgå från att människor är bildbara?}

Inom allmän pedagogik (som kan anses vara den filosofiska grenen inom den kontinentala, tyskspråkiga, pedagogiken) försökte Herbart redan $1806^{4}$ övervinna den alltför snäva distinktionen mellan genetiskt medfödda anlag $\mathrm{i}$ barnet och miljön som påverkar uppväxten. Han präglade det svårt översättbara begreppet "Bildsamkeit" (ungefär: bildbarhet) som en av pedagogikens grundbegrepp. Sedan Herbart har det funnits många beskrivningar och tolkningar av hur man kunde förstå barnets bildbarhet. Jag vill i det följande uppmärksamma

2 Se t.ex. Oelkers, Jürgen: "Allgemeine Pädagogik und Erziehung: Eine Annäherung an zwei Welten aus pragmatischer Absicht" Vierteljahresschrift für wissenschaftliche Pädagogik 82 (2006): 192-214.

3 van Goor, Roel; Heyting, Frieda; Vreeke, Gert-Jan: "Beyond Foundations: Signs of a New Normativity in Philosophy of Education", Educational Theory 54 (2004): 173-192.

4 Herbart, Johann Friedrich, "Allgemeine Pädagogik aus dem Zweck der Erziehung abgeleitet (1806)", in J.F. Herbarts Pädagogische Schriften. Mit Herbarts Biographie herausgegeben, red. Fr. Bartholomäi (Langensalza: Hermann Beyer\& Söhne, 1903). 
ett visst drag i dessa beskrivningar. Wilhelm Flitner, en av huvudgestalterna inom den s.k. geisteswissenschaftliche Pädagogik, skriver t.ex. på olika ställen i hans "Allgemeine Pädagogik" att pedagogen "kan förutsätta" (voraussetzen) att "den växande unga människan och den framskridande vuxna" är bildbar. ${ }^{5}$ Dietrich Benner ${ }^{6}$ eller Marian Heitger ${ }^{7}$ talar i ett likande sammanhang om att pedagogen behöver erkänna (anerkennen) barnets bildbarhet. Frågan som jag vill fokusera på och som kommer att vara det centrala exemplet i denna artikel är hur Flitner, Benner och Heitger och många andra kan vara så optimistiska och helt enkelt utgå från barnets bildbarhet? Hur kan vi vara säkra på att detta antagande är berättigat och bärande för våra vidare pedagogiska betraktelser? Vad stöder sig påståendet på?

Dessa frågor skisserar grovt utgångspunkten för den kritik som riktades mot allmän pedagogik både från den empiriska forskningen i psykologi och de socialvetenskapliga disciplinerna, och från den kritiska, emancipatoriska teorin. Utsagor som Flitners kritiseras från empirisk sida för att inte ännu bevisats. I bästa fall kunde dessa fungera som hypoteser för framtida forskningsansatser.

Företrädarna för Geisteswissenschaftliche Pädagogik och besläktade pedagogiska ansatser utvecklade sina utsagor ur analysen av historiska och samtida pedagogiska texter och ur dessa vetenskapsmännens reflektioner kring egna erfarenheter och observationer. I ljuset av vetenskapens nyliga utveckling borde man inte få betrakta dessa utsagor som fullvärdig vetenskapligt säkrad kunskap, utan som hypoteser eller som antaganden som behöver testas med hjälp av systematisk empirisk forskning. ${ }^{8}$

Teoretikerna inom den kritisk-emancipatoriska riktningen gick även bortom denna kritik då de poängterade att de centrala utsagorna inom Geisteswissenschaftliche Pädagogik inte bara är sådana som vilar på osäker empirisk grund, utan som understöder den rådande ideologin och reproducerar maktförhållandena i samhällssystemet.

Det faktum att fostransprocesser [...] förmedlas samhälleligt hade inte alls blivit föremål för reflektion. Snarare blev fostran förankrad i ett för-samhälleligt, makt-fritt och opolitiskt rum, där barnet skulle komma till "sitt bästa" om bara pedagogen skulle bestämma sig för att realisera "det fostrande handlandets väsen" (Nohl): en idealiserad konception av den goda viljan och den rena pedagogiska inställningen.?

Kritikerna ifrågasatte alltså både källorna, bakgrunden, metoderna och giltigheten av de grundläggande utsagorna som Geisteswissenschaftliche Pädagogik byggde på. Den avgörande frågan för mina vidare tankar är på det viset vad som egentligen kan vara ett tillfredställande bevis eller en tillfredställande metod för att möta kritiken när det gäller utsagor

5 Flitner, Wilhelm, Allgemeine Pädagogik (Stuttgart: Klett-Cotta 1997), 94.

6 Benner, Dietrich, Allgemeine Pädagogik. Eine systematisch-problemgeschichtliche Einführung in die Grundstruktur pädagogischen Denkens und Handelns. (Weinheim, München: Juventa, 2001), 73 eller 222.

7 Heitger, Marian: “Bildsamkeit und Hoffnung” Vierteljahrenschrift für wissenschaftliche Pädagogik 64 (1988): 424.

8 Klafki, Wolfgang et. al., Erziehungswissenschaft 1. Eine Einführung. Funk-Kolleg 7. (Frankfurt/Main: Fischer Taschenbuch Verlag, 1974), 74, egen översättning; se även Brezinka, Wolfgang, Von der Pädagogik zur Erziehungswissenschaft. Eine Einführung in die Metatheorie der Erziehung. (Weinheim/Basel: 1972),101.

9 Mollenhauer, Klaus, Erzichung und Emanzipation. Polemische Skizzen (München: Juventa Verlag, 1968), 24. Egen översättning. 
som "Pedagogen förutsätter bildbarhet i en annan människa"? Jag vill använda mig av en distinktion som Flitner hänvisar till då han beskriver Bildsamkeit som ett av de pedagogiska grundbegreppen.

Flitner skiljer mellan ett erkännande av någons bildbarhet med tanke på en konkret situation (konkrete Bildsamkeit) från erkännandet av bildbarheten som en allmän egenskap som karakteriserar människor som sådana (allgemeine Bildsamkeit):

Den allmänna bildbarheten hänvisar till människans färdighet att som sådan kunna vara flexibel i sin utveckling gentemot intentionella fostrande påverkningar. Däremot kallas det för konkret bildbarhet som kan påträffas inom ett specifikt barn i en specifik situation. ${ }^{10}$

I en konkret situation, där man som pedagog stöter på individuella färdigheter eller svårigheter hos barnet, behöver pedagogen analysera situationen för att kunna förstå de implicita pedagogiska utmaningarna och för att kunna utveckla en handlingsplan. Det vill säga, i fråga om den konkreta bildbarheten kan vi fråga en lärare varför han/hon i denna konkreta situation antar (utgår ifrån, erkänner...) att barnet kommer att kunna öppna sig för vissa innehåll eller pedagogiska metoder, medan en kollega lika väl kan bestrida dessa antaganden. Avgörande är att det i denna situation finns utrymme för en diskussion som t.ex. kunde stöda sig på mätbara egenskaper av barnets bildbarhet (olika pedagogiska, psykologiska tests). I en konkret situation kan vi alltså mycket väl diskutera enskilda pedagogers antaganden om ett barns bildbarhet och kräva en detaljerad redogörelse för hur han/hon har kommit fram till sina slutsatser. Hur barnets konkreta bildbarhet kan tolkas, vilka test som t.ex. kan anses vara mera lämpliga för att mäta XY etc. är sedan både möjliga och nödvändiga frågor att diskutera. Här kan det säkert finnas olika åsikter, men avgörande är i vårt sammanhang till att börja med endast att en diskussion överlag kan finnas.

Jag vill med hjälp av ett exempel från Wittgenstein skilja denna möjlighet till en diskussion kring barnets konkreta färdigheter (den konkreta situationen) från en undran över om barnet överlag är bildbart eller inte (den allmänna frågan).

I andra delen av Wittgensteins "Filosofiska undersökningar" (1953) kan vi hitta en serie med fyra paragrafer, i vilka han påminner oss om användningen av begreppet "att tro" som i detta sammanhang motsvarar användningen av orden "förutsätta" eller "erkänna" i vår diskussion. Han börjar på följande sätt:

"Jag tror att han lider." - Tror jag också att han inte är en automat?

Bara motsträvigt kunde jag uttala ordet i dessa bägge sammanhang.

(Eller är det så här: jag tror att han lider; jag är säker på att han inte är en automat? Nonsens!). ${ }^{11}$

Liksom Flitner skiljer Wittgenstein till att börja med mellan utsagor där vi uttrycker något om en konkret situation från sådana om människor i allmänhet. Jag kan anta att han lider i ett konkret fall. På frågan "Plågas han ännu av sin sjuka rygg?" kan jag svara, "Ja, han har inte talat om att det skulle ha blivit bättre, och jag tycker att han rör sig stelt". Det allmänna

10 Flitner, 1997, s. 88f, egen översättning.

11 Wittgenstein, Ludwig, Filosofiska undersökningar (Stockholm: Thales, 1992), 206. 
antagandet att han inte är en maskin kan ändå inte göras med hänvisning till liknande kriterier. Det finns något lätt skämtsamt i att säga, "Ja, han har upprepade gånger sagt att han är en människa, och han är alltför rörlig för att vara en maskin."12 Vi kan spontant vara benägna att säga att den avgörande skillnaden här ligger i graden av säkerhet, i utsagans giltighet eller kvalitet; medan jag enbart kan tro (anta) att han lider, kan jag vara säker att han är en människa. Men på sitt dialogiska sätt avvisar Wittgenstein denna invändning: Nonsens! Nonsens är inte utsagans innehåll (om denna människa är en maskin eller inte), utan Wittgenstein avvisar meningsfullheten i att tala om säkerhet och giltighet i denna fråga.

Han fortsätter:

Antag att jag säger om en vän: "Han är ingen automat." - Vad meddelar detta, och för vem vore det ett meddelande? För en människa som träffar den andre under vanliga omständigheter? Vad kunde det meddela honom? (Dock på sin höjd att vännen alltid beter sig som en människa, inte då och då som en maskin. $)^{13}$

Låt mig översätta denna tankegång till vårt exempel: Antag att jag säger om ett barn: "Han är bildbar." Vilken information skulle ges här, och för vem skulle detta vara en upplysande information? Till skillnad från kritiken som jag just citerade, kastar Wittgensteins anmärkning fram frågan vilket slags information man skulle ge i fall någon explicit hänvisade till att detta barn är bildbart i allmänhet. När skulle denna information vara hjälpsam och upplysande? ${ }^{14}$. Uttryckt på ett annat sätt: I vilka situationer kan någon på allvar ifrågasätta att ett barn är bildbart i den allmänna meningen? Det är viktigt att se att Wittgensteins sätt att närma sig frågan kommer, så kunde man säga, från det motsatta hållet än de citerade kritikerna till Geisteswissenschaftliche Pädagogik. Medan de frågade: Hur kan du vara säker, frågar Wittgenstein: Hur kan du överlag tvivla?

Wittgenstein fortsätter:

"Jag tror att han inte är en maskin" har, så där utan vidare, ännu ingen mening.

Min inställning till honom är en inställning till en själ. Jag har inte åsikten att han har en själ. ${ }^{15}$

I dessa paragrafer påminner Wittgenstein om att utsagor om människor $\mathrm{i}$ allmänhet (som maskiner eller inte, som bildbara eller inte) inte är hypoteser eller antaganden, som antingen behöver testas och kontrolleras i någon slags empirisk undersökning i framtiden eller som kan kritiseras ifall de "bara" accepteras eller förutsätts. "Det har ännu ingen mening" att anta eller tro något om en annan människa i största allmänhet. Meningen "I människor kan allmän bildbarhet förutsättas" är på det viset varken en "åsikt" som man skulle ha möjlighet att välja eller att byta beroende på olika ideologiska förutsättningar (detta har länge varit ett implicit antagande inom de kritiska-emancipatoriska teorierna). Meningen är inte heller

12 Jfr även Winch, Peter, "Eine Einstellung zur Seele" in Trying to make sense, Winch, Peter (Oxford: Blackwell, 1987), 144.

13 Wittgenstein, 1992, s. 206.

14 Jfr Winch, 1987, s. 144.

15 Wittgenstein, 1992, s. 206. 
resultatet av en intellektuell, rationell slutsats som baserar sig på en logisk kedja av samlade fakta och information (så som kritiken från den empiriska sidan implicerar).

Vad skulle det innebära om kritikerna till Geisteswissenschaftliche Pädagogik hade rätt? Skulle vi ändra vår inställning till ett barn på ett grundläggande sätt och behandla henne eller honom som inte bildbar alls, ifall det funnits en möjlighet att hitta ny empirisk kunskap kring människans allmänna bildbarhet? Som man lätt kan se skulle detta leda till långtgående moraliska problem, som vi känner ur diskussioner om abort eller eutanasi (när börjar en människa att vara människa, när slutar hon vara det?). Jag tror inte att de citerade kritikerna ville föra detta slags diskussion med filosoferna.

I situationer där vi har att göra med allmänna utsagor om en människa uttrycker vi inte en empirisk bevisbar sanning, utan allmänna utsagor om människan speglar, i Wittgensteins ord, vår "inställning till en själ". Om man följer denna tanke så röjer kravet efter hållbara bevis inte bara forskarens oskyldiga nyfikenhet som enbart vill vara säker innan han/hon vill förutsätta eller anta något. Snarare uttrycker begäran efter bevis i sig talarens inställning till andra människor. Jag återkommer till denna tanke.

\section{Om skillnaden mellan empiriska och begreppsligt konstitutiva frågor}

Diskussionen kring den kritik som den pedagogiska filosofin har fått (här exemplifierad av allmän, resp. geisteswissenschaftliche pedagogik) kastar ett intressant ljus på utgångsfrågan "Varför behövs pedagogisk filosofi?"

Flitner lyckas till att börja med uppmärksamma en central skillnad i diskussionen om människans bildbarhet, den mellan konkret och allmän bildbarhet. Det verkar dock som om han och många andra pedagogiska filosofer inte förmådde uppskatta det kunskapsmässiga djupet som denna skillnad vilar på eftersom man tills idag inte lyckats tillbakavisa den empiriska och emancipatoriska kritiken tillräckligt tydligt. Denna kritik som riktade sig mot sådana centrala, allmänna utsagor i allmän pedagogik gräver på det sättet på rätt ställe. Allmän pedagogik verkar inte ha förstått vilken karaktär deras olika utsagor har och hur dessa relaterar till andra former av kunskap, t.ex. till empiriska bevis och fakta. Den empiriska och emancipatoriska kritiken lyckades dock inte heller klargöra diskussionen, utan har enbart avvisat dessa utsagor som ur deras perspektiv verkar ogrundade och har undvikit dem i sina egna teorier.

Den aktuella diskussionen med tanke på bildbarhet präglas fortfarande av en oklarhet mellan denna empiriskt vetenskapliga referensram och terminologi å ena sidan och den begreppsligt konstitutiva insikten om människans allmänna bildbarhet å andra sidan. Keller sammanfattar t.ex. sin komparativa studie om diskussionen kring begreppet Bildsamkeit i den tyskspråkiga litteraturen mellan 1981 och 2000 så att det främsta problemet i samband med bildbarhet inte ligger i "dess existens utan i möjligheten att fastställa den"16 Nieberg,

16 Keller, Titus, Wilhelm Flitners Stereotyp "Bildsamkeit" (1931ff) im Vergleich zum Bildsamkeitsgebrauch und -verständnis zwischen 1981-2000. Sammlung pädagogischer Beiträge. Editor PD Dr. Werner Keil. (Regensburg: S. Roderer Verlag, 2000), 122. Egen översättning och kursivering. 
som undersökte begreppet Bildsamkeit hos Herbart och Flitner, vågar på ett liknande sätt inte tala om mer än "indicier" som stöder antagandet om bildbarhetens "existens"." Den filosofiska diskussionen kring pedagogiska frågor och fenomen verkar i sådana frågor nå en återvändsgränd då man å ena sidan tydligt ser att det grundläggande antagandet om t.ex. bildbarhet inte kan förnekas (och fram för allt inte får förnekas ${ }^{18}$ och att bildbarhet därför behöver förstås som konstitutivt för den pedagogiska verksamheten. Men samtidigt som man har denna insikt verkar man å andra sidan se sig tvungen att behöva förstå och uttrycka sig själv inom den snäva kontexten av en (empirisk) vetenskaplighet som kräver hållbara forskningsresultat, bevis och logiska argumentationskedjor för att få tala om bildbarhetens "faktiska" existens. Man rör sig med en empirisk, vetenskaplig terminologi för att uttrycka sådana pedagogisk-filosofiska insikter som just inte kan förstås med hjälp av empirin och inom vetenskapens logik.

Som en första slutsats ur denna diskussion vill jag därför fastställa att det finns frågor i pedagogik som inte kan besvaras på med hjälp av en (empirisk) vetenskap. Detta må i sig inte vara en ny insikt i den vetenskapsteoretiska debatten i pedagogik, snarare har man sedan länge kunnat skilja empiriska från andra mera filosofiska frågeställningar. ${ }^{19}$ Avgörande för min vidare diskussion är dock å ena sidan att denna skillnad uppenbarligen är svår att iaktta eftersom dessa två olika språk, det empiriska och det (grovt sagt) filosofiska språket, ofta blandas ihop. Man drar sällan tillräckligt tydliga gränser mellan områdena. Detta har konsekvenser för vår självförståelse som pedagogiska filosofer i dialog med de empiriska vetenskaperna. $\AA$ andra sidan är det ofta inte entydigt vad man skiljer empiriska frågor ifrån. Den icke-empiriska motparten i en tänkt dikotomisk uppställning beskrivs delvis som begreppsligt konstitutiva frågor, men allt för ofta också som "normativa". Det gäller att reda ut att en filosofi som ägnar sig åt begreppligt konstitutiva frågor inte av nödvändighet samtidigt är normativ.

\section{Om den väsentliga skillnaden mellan filosofi och empirisk vetenskap}

Utgångsfrågan "Varför pedagogisk filosofi?" implicerar tanken att det finns ett alternativ till den filosofiska reflektionen i pedagogik. Filosofi som sådant och filosofins olika delområden liksom pedagogisk filosofi har sedan över 100 år jämförts och kontrasterats med, grovt sagt, vetenskap, som jag i denna artikel för tydlighetens skull ganska långt förstår som empirisk. Min diskussion kring barnets bildbarhet försökte exemplifiera den kritik som filosofin konfronteras med som påstår att filosofernas reflektion inte kan leda till mer än förberedande, subjektiva, hypotetiska resultat eller resultat av den s.k. andra ordningen. Idag

17 Nieberg, Kevin, Der Begriff der "Bildsamkeit". Ein Konstrukt "Allgemeiner Pädagogik" bei Johann Friedrich Herbart und Wilhelm Flitner. Sammlung pädagogischer Beiträge. Editor PD Dr. Werner Keil. (Regensburg: S. Roderer Verlag, 2002), $92 \mathrm{ff}$.

18 Jfr Heitger 1988.

19 Jfr Benner, Dietrich och Brüggen, Friedhelm, Geschichte der Pädagogik. (Stuttgart: Reclam, 2011). $352 \mathrm{ff}$. 
kan man höra röster både från pedagogiska filosofer själv och från forskare inom andra pedagogiska områden som kräver att den pedagogiska filosofin borde försöka bli mera lik de empiriska pedagogiska vetenskapsområdena. Om vi t.ex. betraktar den tyskspråkiga diskussionen så klagar man där på att pedagogisk filosofi lider av en brist på positiv, vetenskaplig kunskap. ${ }^{20}$ Varken filosofins forskningsresultat eller dess utbildningsprogram motsvarar de aktuella samhälleliga behoven. ${ }^{21}$ Därför kräver man att filosofin borde närma sig de empiriska pedagogiska vetenskaperna, t.ex. genom att ta delar av deras metoder eller resultat i beaktande. ${ }^{22}$ Dessa författare föreslår idag det som redan under den empiriska frammarsch på 1960/70-talet diskuterades inom både den tyskspråkiga, nordiska och den anglosaxiska pedagogiken, som i sin tur motsvarar den kritik som filosofin konfronterades med i början av 1900-talet då neopositivismen och den s.k. logiska empirismen kritiskt föreslog att "filosofin i vår tid måste bli en mer eller mindre teknisk specialvetenskap som arbetar med begreppskonstruktion och teoribyggande och en närmast ingenjörmässig inställning till de filosofiska problemen (Carnap, Tarski, m.fl.).".33

Dessa argument utgår från tanken att filosofi och empirisk vetenskap är verksamheter som i grunden är jämförbara. Filosofi, enligt den implicita kritiken, är helt enkelt inte lika bra (läs: exakt, effektiv, applicerbar, konkret...) som vetenskapen. Det medför å ena sidan det som vi just har sett, nämligen en benägenhet att uttrycka egna filosofiska reflektioner med hjälp av den empiriskt vetenskapliga terminologin. Å andra sidan behöver filosofer allt mera legitimera sitt arbete och sin "produktivitet" med hjälp av kategorier som må vara passande för den empiriska forskningen men som inte är det för den filosofiska. Med tanke på dessa sätt att diskutera filosofins akademiska plats och vikt upplever jag att den (pedagogiska) filosofin borde ägna sig mer intensivt åt frågan hur vi förstår vår egen disciplinära särart och vårt säregna bidrag till den pedagogiska diskussionen.

Jag vill här även anknyta till en tanke i Wittgensteins senare filosofi och som kan kasta ljus på detta problem. Enligt Wittgenstein skiljer sig filosofisk reflektion väsentligt från vetenskaplig forskning. I förordet till hans "Philosophical remarks" (1930) som postumt publicerades i "Culture and Value" (1977) beskriver han denna grundläggande skillnad på följande sätt:

This book is written for such men as are in sympathy with its spirit. This spirit is different from the one which informs the vast stream of European and American civilization in which all of us stand. That spirit expresses itself in an onwards movement, in building ever larger and more complicated structures; the other in striving after clarity and perspicuity in no matter what structure. The first tries to grasp the world by way of its periphery - in its variety; the second at its centre - in its essence. And the first adds one construction to

20 Mollenhauer, Klaus: “Über Mutmaßungen zum 'Niedergang' der Allgemeinen Pädagogik - eine Glosse“, in Zeitschrift für Pädagogik 42 (1996): 284.

21 Se t.ex. Oelkers 2006

22 Vogel, Peter: "Stichwort: Allgemeine Pädagogik", in Zeitschrift für Erziehungswissenschaft 2 (1998): 157.

23 Stenlund, Sören, Filosofiska uppsatser. (Skellefteå: Norma, 2000), 16f. Jfr även Carr, Wilfred, "Philosophy and Education", in Journal of Philosophy of Education 38 (2004): 55-73, för en översikt över den anglo-saxiska diskussionen. 
another, moving on and up, as it were, from one stage to the next, while the other remains where it is and what it tries to grasp is always the same..$^{24}$

I am not interested in erecting a building but in having the foundations of possible buildings transparently before me.

So I am aiming at something different than the scientists \& my thoughts move differently than do theirs. ${ }^{25}$

I dessa få rader, som vid första ögonkastet kan se ut som en filosofs elitistiska eller antivetenskapliga inställning, skisserar Wittgenstein några viktiga skillnader mellan vetenskapen och filosofi. Medan den vetenskapliga verksamheten försöker skrida framåt, där målet är att ständigt öka på kunskapsmängden som i idealfallet bygger allt större system ur den tidigare och nyskapade forskningen och kunskapen, stannar filosofin liksom på stället och söker nå förståelse och klarhet om den grund som kunskapen vilar på. Bilden av filosofin som den verksamhet som lägger grunden för vetenskapen är dock lätt förvirrande. Föreställer man sig vetenskapens resultat som tegelstenar som man kan bygga med tänker man ofta på filosofin som själva byggnadens fundament. Fundamentet består då i denna bild av liknande material och stenar; de är bara större och stabilare, eller bara mera allmänna och abstrakta. I denna analogi blir det svårt att se den väsensskillnad mellan filosofi och vetenskapen som Wittgenstein hänvisar till. Att få förståelse för och klarhet om grunden till en verksamhet, t.ex. till den vetenskapliga verksamheten i pedagogik, handlar i min tolkning av Wittgenstein dock om att påminna sig om den mening som vi ser i de olika begrepp och frågor som ingår i våra forskningsfrågor och vetenskapliga utredningar. Att få syn på mening är dock en annorlunda tankemässig rörelse än att foga ihop olika informationsbitar till ny faktakunskap. Att kunna se mening är inte beroende av att man har vissa fakta eller bevisad information till hands. Den filosofiska rörelsen har i denna läsning snarare karaktären av en insikt. Insikten kännetecknas av aha-effekten; allt som man behövde veta för att få en insikt hade egentligen hela tiden funnits öppet framför en utan att man förmådde se det. Man slås av den och man förstår inte hur man varit så blind. Wittgenstein jämför därför också filosofisk verksamhet med påminnelser. Det är inte något nytt som man får veta; det är snarare en hjälp för att få syn på den grund och de grundantaganden som man redan vilat sig på.

I fall vi alltså mäter kvaliteten i den akademiska verksamheten i form av positiv kunskapsproduktion som visar sig i tillämpbara resultat kommer filosofi i Wittgensteins mening av nödvändighet att bli underkänd.

Sören Stenlund uppmärksammar ett allvarligt problem som vi skulle råka ut för i fall vi likställde filosofin med vetenskapen. Han skriver att

[o]m filosofin skall ha något kvar av anspråket på att vara ett sätt att med tänkande och intellekt söka nå klarhet i de 'mest grundläggande frågorna', de frågor som gäller de 'yttersta gränserna' så kan den själv inte vara en sådan specialvetenskap. ${ }^{26}$

24 Wittgenstein, Ludwig, Philosophical Remarks. (Oxford: Blackwell, 1994), 7.

25 Wittgenstein, Ludwig, Culture and Value. Revised Edition. (Oxford, Malden: Blackwell, 1998), 9e.

26 Stenlund, 2000, s. 16. 
En central anledning till att peka på den grundläggande skillnad mellan den vetenskapliga och den filosofiska verksamheten ligger för Wittgenstein, och för Stenlund i hans spår, alltså i följande tanke: Om filosofin vore jämförbar med andra vetenskapliga grenar skulle filosofin enbart tävla med de andra disciplinerna om frågan om vem som äger främsta auktoritet för att kunna hävda giltigheten i den kunskap som resulterar ur den egna verksamheten. En sådan diskussion skulle röra sig kring frågan om den bästa och mest säkra grunden eller de bästa argumenten som vår kunskap vilar på. Lyssnar man på den nutida debatten kring filosofins plats och roll verkar detta visserligen som antingen den mest önskvärda eller den oundvikliga situationen. Stenlund utvecklar dock att det avgörande i detta synsätt är att det bygger på ett implicit metafysiskt antagande. Om vi antar att filosofin enbart är en disciplin bland andra, implicerar vi att frågan "vad är sant?" bara kan leda till olika positioner eller ståndpunkter som kämpar om det bästa argumentet. Det är en relativistisk förförståelse om sanning som i sig inte underbyggts. ${ }^{27}$

Låt mig tydliggöra denna tanke med hjälp av vår diskussion kring barnets bildbarhet. Kritikerna till den geisteswissenschaftliche Pädagogik kritiserade dessa grundläggande utsagor, t.ex. om människans allmänna bildbarhet, som osäkra, enbart hypotetiska eller ideologiskt färgade subjektiva påståenden vars sanningshalt återstår att bli testad. Wittgensteins och Stenlunds argument är följande: Frågan som Geisteswissenschaftliche Pädagogik diskuterade med sina kritiker var: "Är utsagan 'Människan är allmänt bildbar' sann eller inte?" Utsagans sanning hängde i denna diskussion enbart på framgången i att argumentera för varför de egna tillvägagångssätten och forskningsmetoderna tillhandahåller tillförlitliga resultat, eller, som i vårt fall, att kritisera utsagans sanningshalt på grund av att man inte kan övertyga den andra sidan om att man använt sig av tillförlitliga metoder för att komma fram till berättigade antaganden. Man kunde förtydliga denna situation med bilden att en filosof och en empiriker står framför ett barn. Filosofen säger "Detta barn är bildbart i allmän mening", medan empirikern svarar undrande "Hur kan du vara säker på att detta antagande är sant?" Vi såg att en utsaga om människans allmänna karaktär inte kan förstås som enbart en personlig åsikt eller en hypotes, snarare uttrycker filosofen (likaså empirikern som vi kommer att se) sin inställning till barnet. Ändå behandlas filosofens utsaga i denna situation som om den uttryckte enbart en viss (personlig eller filosofisk) ståndpunkt, och empirikern visar sig inte bli övertygad av denna ståndpunkt på grund av bristande säkerhet i filosofens metoder. Sanningen i sådana enskilda åsikter eller ståndpunkter är i denna situation alltså relativ till metodernas och argumentens kraft att övertyga. Som vi såg gick den filosofiska sidan både med på denna debatt och förmår tills idag inte att tillbakavisa empirikerns krav på mer säkra metoder som meningslösa i sammanhanget. Fortfarande står filosofen framför barnet

27 Jfr Stenlund 2000, s. 45-75. För en utförligare diskussion och fördjupad förankring av dessa tankar se Stenlunds tre första uppsatser i hans samling "Filosofiska uppsatser" (2000) om "Språk och livsform:några drag i Wittgensteins filosofi", "Strävan efter allmängiltighet" och "Är filosofiska problem bara missförstånd?" 
och undrar hur han eller hon kunde hitta mer än "indicier"28 som skulle ge möjligheten att på riktigt "fastställa bildbarhetens existens". ${ }^{29}$

Wittgensteins anmärkningar kring en annan människas lidande eller varande hjälpte dock att vända blicken från denna fråga. Det allmänna antagandet att människor är bildbara gick inte att ifrågasättas och diskuteras på samma sätt som det konkreta antagandet, eftersom det uttrycker vår grundläggande inställning till en annan människa och till vårt liv med andra; eller annorlunda uttryckt den mening som vi ser i begreppet "människa" eller "barn". Man hamnar i djupt moraliska problem i fall man faktiskt skulle förstå den egna inställningen i termer av preliminära åsikter eller hypoteser. I så fall borde vi byta dessa grundläggande förhållningssätt till andra människor allt eftersom nya fakta dyker upp (förutsatt att en sådan "bevisföring" överlag skulle vara möjlig). Filosofen skulle då vara tvungen att behandla barnet som om det inte var allmänt bildbart, dvs. som vilket annat materiellt objekt som helst - åtminstone så länge inte andra säkrare bevis någon gång i framtiden talade för barnets allmänna bildbarhet. Vår spontana reaktion är att så här kan det inte vara, man vill svara "Människor är ju bildbara i allmän mening". Hur kan man förstå denna spontana reaktion om den inte bara är en viss ståndpunkt?

Wittgensteins paragrafer försöker uppmärksamma oss på att det finns en grundläggande skillnad i hur vi umgås med människor och hur vi behandlar föremål. ${ }^{30}$ Peter Winch skriver att vi har dessa olika förhållningssätt oberoende av om vi vill det eller inte; de är inte valda ståndpunkter. ${ }^{31}$

There is no question here of an attitude which I can adopt or abandon at will. My Einstellung [inställning, B.S.] may no doubt be strengthened, weakened or modified by circumstances and to some extent by thought too, but usually, in given circumstances, it is a condition I am vis-à-vis other human beings without choosing to be so. ${ }^{32}$

Att kritisera Flitner och andra filosofer för att inte tillräckligt ha kunnat redogöra för varifrån de tar sin pedagogiska utgångspunkt beaktar inte denna grundläggande skillnad mellan människor, levande varelser och den fysiska världen, en skillnad som vårt liv vilar på. Det som kunde kallas sanning i denna skillnad vilar i sin tur inte på något slags bevis eller faktakunskap som man kunde komma fram till med hjälp av (empiriskt) vetenskapliga metoder. Sanningen vilar på det liv vi lever och i vilket denna skillnad i otaliga konkreta situationer spelar en avgörande roll. På det viset påminner Wittgensteins filosofi om att sanningen i denna fråga inte kan vara relativ.

Tyvärr har den pedagogiska filosofin länge gått med på detta spel och har därmed "accepterat" att dess grundläggande utsagor som enbart ståndpunkter i en kamp om vem

28 Nieberg, 2002, s. 92.

29 Keller, 2000, s. 122.

30 En liknande insikt om skillnaden mellan att förhålla sig mot ett subjekt eller ett objekt finns likaså hos Martin Bubers distinktion mellan begreppsparen Jag-Du och Jag-Det, eller hos Emanuel Lévinas bild av den andre ansikte, eller ytterligare hos Georg Herbart Meads skillnad mellan I och me.

31 Jfr Winch, 1987, s. 144 och 149.

32 Winch, 1987, s. 149 f. 
som har de bästa argumenten och metoderna. Man accepterade en relativistisk syn i sådana frågor som är konstitutiva för själva den pedagogiska verksamheten. I samma stund som man gick med på diskussionen om vems metoder och argument som är mera hållbara accepterade den pedagogiska filosofin att den egna verksamheten i princip är jämförbar med den empiriskt vetenskapliga.

Mot denna bakgrund kan Wittgensteins formulering förstås som att han inte vill bygga upp en egen struktur eller utveckla ett eget system. Filosofin borde enligt honom inte sträva efter att vara en möjlig teori, ståndpunkt eller doktrin bland andra. Snarare lyfter han redan i sitt tidigare verk Tractatus logicus philosophicus fram filosofin som en verksamhet. ${ }^{33} \mathrm{En}$ filosofisk diskussion borde då inte engagera sig i sådana relativistiska strider som jag just har beskrivet. Wittgensteins anmärkningar kring lidande och maskiner öppnar snarare ögonen för frågor om vad vi gör då vi t.ex. antar, erkänner eller ifrågasätter någon annans bildbarhet, och vad vi gör när vi kritiserar Flitner, Benner och Heitger för att inte kunna bevisa deras utsagor kring människans allmänna bildbarhet? Medan man lätt frestas att stirra sig fast på frågor kring den metodologiska och epistemologiska säkerheten i pedagogiska utsagor borde vi öppna våra ögon för denna mer reflekterande, meningsseende nivå där vi kan undra över varför vi i olika situationer kräver säkerhet och giltighet. Vilka dialogiska drag gör vi i våra pedagogiska diskussioner när vi t.ex. accepterar, tillbakavisar eller utgår från olika utsagor?

I dessa reflektioner ligger en viktig första insikt som svarar på utgångsfrågan "Varför pedagogisk filosofi?". Den filosofiska reflektionen är inte jämförbar med det vetenskapliga tillvägagångssättet. Därför borde och får den filosofiska uppgiften inte anpassas till ett mera empiriskt vetenskapligt sätt att söka kunskap. Filosofins frågor, tankevägar och resultat har en annorlunda karaktär i den bemärkelsen att den pedagogiska filosofin har en säregen plats när vi på olika sätt försöker nå förståelse i pedagogiska frågor. Eller i Wittgensteins ord: "So I am aiming at something different than the scientists \& my thoughts move differently than do theirs". ${ }^{4}$

\section{Den pedagogiska filosofins uppgift - en mycket grov skiss}

Detta är enbart ett första steg som den pedagogiska filosofin borde bli medveten om för att tydliggöra sin legitimitet inom den akademiska världen i allmänhet, och inom de pedagogiska fakulteterna i synnerhet. Än mer filosofiskt intressant är diskussionen om hur man kan förstå karaktären av de frågor som inte är empiriskt vetenskapliga och som jag hittills kallat "konstitutivt begreppsliga" eller ibland ännu mer allmänt "filosofiska". Jag kan här enbart antyda vissa linjer och riktningar som en sådan diskussion om den filosofiska självförståelsen kunde ta.

33 Wittgenstein, Ludwig, Tractatus Logico Philosophicus. Werkausgabe Band 1. (Frankfurt/Main: Suhrkamp, 1999), \$4.112. Stenlund, 2000, s.16.

34 Wittgenstein, 1998 , s. 9 e. 
En första filosofisk uppgift kunde vara att inom ett pedagogiskt problem skilja på sådana frågor som kan undersökas empiriskt vetenskapligt från sådana som inte kan bearbetas på det sättet. Den epistemologiska diskussionen, formulerad i frågor som "Hur kan vi veta något med säkerhet?" "Vilka bevis finns för och med vilka forskningsmetoder kan man utreda X?" föregås då av det som jag ovan kallade en meningsseende nivå: Varför avkräver vi en allmän giltighet för vissa utsagor eller antaganden? Av vem avkrävs dylika berättiganden och vilka dialogiska drag görs i detta syfte? Empirikern som undrar om filosofens allmänna antagande om barnets bildbarhet baserar sig på säkra grunder ger inte uttryck för sin rena nyfikenhet, forskarheder och vilja att vara säker på sin sak innan han eller hon tar något för givet. I själva verket har empirikern redan tagit ställning i en mycket mera grundläggande fråga. Han eller hon har ifrågasatt den fundamentala skillnad som visar sig i våra liv och våra spontana reaktioner på en annan människa (vi talar med, hälsar på, undviker henne, o.s.v.) och våra spontana reaktioner på materiella objekt (som vi inte hälsar, talar till, eller försöker fostra eller undervisa). Empirikern som kräver ett säkert grundläggande av barnets allmänna bildbarhet är inte en neutral frågeställare utan har med hjälp av sin fråga gjort ett visst drag i den pedagogiska diskussionen - oberoende av om han eller hon ville det eller inte.

I en konstitutivt begrepplig diskussion gäller det på det viset att uppmärksamma den inställning till det liv som vi lever som uttrycker sig i varje (pedagogisk) fråga och i varje (pedagogisk) utsaga. Det betyder att filosofin möjligtvis kan bidra med en analys kring vilka frågor som är empiriskt vetenskapliga och vilka som är av konstitutivt begreppslig karaktär. Men det innebär inte ännu att filosofin intar en normativ roll. Filosofin föreskriver inte normativt vad de enskilda människorna/forskarna, pedagogerna o.s.v. måste anse vara rätt eller fel i dessa frågor. Min diskussion kring barnets bildbarhet var på det viset inte avsett för att säga att empirikern har fel inställning till barnet när han/hon kräver säkra bevis. Filosofin frågar snarare empirikern om han eller hon är medveten om att han eller hon genom sin fråga ifrågasätter några av de mest fundamentala utgångspunkterna i våra liv. Frågan som kunde ställas är "Kan och vill du på allvar tvivla på en människas allmänna bildbarhet? Vill du kritisera någon för att den behandlar en annan person som en människa, vilket t.ex. uttrycker sig genom att den i sitt förhållningssätt inte betvivlar möjligheten att tillskriva den andra vissa egenskaper?" Ett drag som här antyds är att en sådan reflekterande nivå ställer vissa frågor tillbaka till den som börjar fråga. Att peka på ett visst pedagogiskt problem är på det viset redan i sig något som kan och borde bli föremål för en pedagogisk och filosofisk reflektion. Vem anser att vilka företeelser eller beteenden är värda att undersöka? Varför tas vissa frågor upp för en pedagogisk utredning och inte andra? Varför formuleras ett problem med vissa och inte med andra begrepp?

Ett möjligt fruktbart sätt att gå vidare med dessa frågor, vilket jag enbart kan antyda här, är att iaktta deras moraliska dimension. De väcker frågan om vilken inställning vi har till andra människor och vilka beröringspunkter denna inställning har till vad vi uppfattar som ett gott liv för människor. För att än en gång återgå till Wittgensteins diskussion om en inställning till en själ, kan vi tänka oss ett sammanhang då utsagan "Han är inte en maskin!" 
blir meningsfull inte som en grundläggande epistemologisk kategori utan som en moralisk kritik. Vi kan t.ex. tänka oss att vi riktar den till en förälder som pressar på sitt barn ett hårt träningsprogram för att nå goda idrottsresultat och inte lägger märke till att barnet verkar vantrivas i träningen. Vad vi då uppmärksammar är att det finns annat $i$ ett mänskligt liv än idrottsframgångar och att det är viktigt att vi ägnar oss åt aktiviteter som vi har lust till och som känns meningsfulla. Att påminna om att ett barn eller en vuxen människa är bildbar i en pedagogisk situation kan likaså vara ett sätt att uppmärksamma att mänskligt lärande t.ex. inte enbart är en fråga om informationsinhämtning, utan att ett vidare bildningsbegrepp också innefattar känslor, fantasi och kreativitet.

Att filosofiskt klargöra vilka moraliska förhållningssätt som kan komma till uttryck i dylika utsagor kunde ses som en av den pedagogiska filosofins uppgifter. Den filosofiska reflektionen kommer ändå inte med normativa rekommendationer, alltså innehållsliga svar i dessa moraliska frågor, utan kräver att var och en som berörs av problematiken själv reflekterar över sin egen inställning $i$ frågan.

\section{Litteratur:}

Bengtsson, Jan, “Editorial. Special Issue: Philosophy of Education”, in Nordisk Pedagogik 21 (2001): 129-133. Benner, Dietrich: Allgemeine Pädagogik. Eine systematisch-problemgeschichtliche Einführung in die Grundstruktur pädagogischen Denkens und Handelns. Weinheim, München: Juventa: 2001.

Benner, Dietrich, och Brüggen, Friedhelm, Geschichte der Pädagogik. Stuttgart: Reclam, 2011.

Brezinka, Wolfgang, Von der Pädagogik zur Erziehungswissenschaft. Eine Einführung in die Metatheorie der Erziehung. Weinheim/Basel: 1972.

Carr, Wilfred, "Philosophy and Education", in Journal of Philosophy of Education 38 (2004): 55-73.

Flitner, Wilhelm, Allgemeine Pädagogik. Stuttgart: Klett-Cotta, 15. ed. 1997.

van Goor, Roel; Heyting, Frieda; Vreeke, Gert-Jan, "Beyond Foundations: Signs of a New Normativity in Philosophy of Education", in Educational Theory 54 (2004): 173-192.

Heitger, Marian, "Bildsamkeit und Hoffnung", in Vierteljahresschrift für wissenschaftliche Pädagogik 64 (1988): 416-432.

Herbart, Johann Friedrich, "Allgemeine Pädagogik aus dem Zweck der Erziehung abgeleitet (1806)". In J.F. Herbarts Pädagogische Schriften. Mit Herbarts Biographie herausgegeben, redigerad av Fr. Bartholomäi. Langensalza: Hermann Beyer\& Söhne, 1903.

Keller, Titus, Wilhelm Flitners Stereotyp "Bildsamkeit" (1931ff) im Vergleich zum Bildsamkeitsgebrauch und -verständnis zwischen 1981-2000. Sammlung pädagogischer Beiträge. Editor PD Dr. Werner Keil. Regensburg: S. Roderer Verlag: 2000.

Klafki, Wolfgang et. al., Erziehungswissenschaft 1. Eine Einführung. Funk-Kolleg 7. Frankfurt/Main: Fischer Taschenbuch Verlag, 1974.

Mollenhauer, Klaus, Erziehung und Emanzipation. Polemische Skizzen. München: Juventa Verlag, 1968.

Mollenhauer, Klaus, "Über Mutmaßungen zum 'Niedergang' der Allgemeinen Pädagogik - eine Glosse“, in Zeitschrift für Pädagogik 42 (1996): 277-285.

Nieberg, Kevin, Der Begriff der "Bildsamkeit". Ein Konstrukt "Allgemeiner Pädagogik" bei Johann Friedrich Herbart und Wilhelm Flitner. Sammlung pädagogischer Beiträge. Editor PD Dr. Werner Keil. Regensburg: S. Roderer Verlag: 2002. 
Oelkers, Jürgen, "Allgemeine Pädagogik und Erziehung: Eine Annäherung an zwei Welten aus pragmatischer Absicht", in Vierteljahresschrift für wissenschaftliche Pädagogik, 82 (2006): 192-214.

Stenlund, Sören, Filosofiska uppsatser. Skellefteå: Norma, 2000.

Vogel, Peter, "Stichwort: Allgemeine Pädagogik", in Zeitschrift für Erziehungswissenschaft 2 (1998): 157-180. Winch, Peter, "Eine Einstellung zur Seele", in Trying to make sense, Winch, Peter, 140-153, Oxford: Blackwell, 1987.

Wittgenstein, Ludwig, Filosofiska undersökningar. Stockholm: Thales, 1992.

Wittgenstein, Ludwig, Culture and Value. Revised Edition.Oxford, Malden: Blackwell, 1998.

Wittgenstein, Ludwig, Tractatus Logico Philosophicus. Werkausgabe Band 1. Frankfurt/Main: Suhrkamp, 1999.

Wittgenstein, Ludwig, Philosophical Remarks. Oxford: Blackwell, 1994. 